\title{
ASTER Garden: A Novel Vegetable Garden Design for International Development
}

\section{Vegetable gardening as a development strategy}

In many developing nations, vegetable gardening is important for food production and as an income source (Beverly et al., 1991; Bittenbender, 1985; Jack and Caldwell, 1988; Midmore et al., 1991; Venkataratnan, 1992). Accordingly, vegetable gardening projects that promote production for home consumption, local sale, or export are important components of many agencies' development projects. Although the crops selected for these projects vary tremendously due to climate, objectives, and local preferences, they often include tomato (Lycopersicon esculentum Mill.), pepper (Capsicum annuum L.), eggplant (Solarium melongena L.), summer squash (Cucurbita pepo var. melopepo L.), winter squash (Cucurbita pepo var. pepo (L.),bean (Phaseolus vulgaris L.), cowpea [Vigna unguiculata (L.) Walp.], onion (Allium cepa L.), and cabbage (Brassica oleracea var. capitata L.). Other crops may include sweet corn (Zea mays var. rugosa Bonaf], okra [Abelmoschus esculentus (L.) Moench], watermelon [Citrus lanatus (Thunb.) Matsum. \& Nakai], cucumber (Cucumis sativus L.), and sweetpotato [Ipomoea batatas (L.) Lam.].

In West Africa, irrigated vegetable production schemes often involve installing 1-mdiameter hand-dug, concrete-lined wells, an expensive undertaking that requires long-term commitment to a particular location. In many low-income areas, watering cans are used to distribute water by hand, a labor-intensive process. Furthermore, although individual gardeners intensively manage their plots, the need for foot paths throughout cooperative schemes reduces the efficiency of using the total irrigated area. In contrast, in some areas of West Africa (as I observed in Niger), shallow groundwater (3 to $10 \mathrm{~m}$ deep) can be tapped using inexpensive small-diameter, hand-drilled wells lined with polyvinylchloride pipe. Such schemes can be developed at much lower. cost, making the benefits of vegetable gardening widely available to the local popu-

Received for publication 10ct. 1992. Accepted for publication 3 10ct. 1992. The cost of publishing this paper was defrayed in part by the payment of page charges. Under postal regulations, this paper therefore must be hereby marked advertisement solely to indicate this fact.

Front cover Overhead view of crop arrangement in seven ASTER garden "stars" early in crop development. A central water source in each star supplies irrigation to six rows, each $6 \mathrm{~m}$ long and $0.5 \mathrm{~m}$ wide. (Photograph by Ted Smith) lation. In such a scheme, efficient management of the irrigated area becomes more important than using the entire area.

\section{ASTER garden design}

Based on this reasoning, the Alt-erect/ Spreading/Trailing Extensive Radial (ASTER) vegetable garden design was developed (Fig. $1)$. The acronym suggests the star-shaped arrangement of crops in six rows, each $6 \mathrm{~m}$ long and $0.5 \mathrm{~m}$ wide, radiating from a central water source. Water can be distributed by hand, furrow, or drip irrigation technology. Tall (alt-erect) crops (e.g., corn and okra) are located near the center of the design, where rows are close together. Rows diverge with increasing distance from the center, and crops with spreading growth habits (e.g., tomato, eggplant, and squash) are located here. At the extremes of the rows, trailing crops (such as watermelon, cucumber, and sweetpotato) use the large area between adjacent rows. The effect is an efficient use of intensively man'aged irrigated land, with room for trailing crops to occupy nonirrigated land space between rows. This design can be installed inexpensively and repeated to provide as much production area as needed.

\section{Proving the concept}

Research at the Georgia Experiment Station in 1991 and 1992 used the ASTER garden design to test and demonstrate its application. In 1991, rows were divided into six plots, each $1 \mathrm{~m}$ long. In 1992, four 1.5-m-long plots were used. With six rows per star and six stars, there were 36 corresponding plots relative to the center. Each star had a hose outlet supplied by the municipal water system; drip irrigation distributed water down each row. A seventh star, surrounded by the other six, supplied water by gravity flow through drip irrigation tubing from a 200 -liter drum that was filled, as needed for irrigation, from the municipal water system (Fig. 2). Plots were established by rototilling a $50-\mathrm{cm}$-wide row to a $10-\mathrm{cm}$ depth. Crops were direct-seeded or transplanted; a mulch of small-grain straw, $10 \mathrm{~cm}$ thick, was applied after stand establishment. After harvest in 1991, crop residues were removed and a small-grain cover crop was sown in crop rows. The cover crop was rototilled in 1992 before planting, and mulch was reapplied in 1992. Areas between rows were sprayed with herbicide and mowed to limit weed growth.

Proceeding from the center to outermost plots, the following crops were tested in 1991: corn, okra, or sunflower tomato; eggplant or pepper bean, cowpea, or sweetpotato; squash cucumber or watermelon. The solanaceous crops, cucurbits, and sweetpotato were grown from transplants, while the other crops were direct-seeded. Corn, okra, sunflower, beans, and cowpeas were sown in two rows per plot and thinned to a population of 10 (corn and sunflower) or 20 (okra, berm, and cowpea) plants per plot. There were two tomato plants of two fresh-market cultivars, or four plants of two canning cultivars, per plot. Eggplant, pepper, and sweetpotato were planted at four per plot. Squash, cucumber, and watermelon were planted at two per plot. Two or more cultivars of each crop were grown in replicated tests.

In 1992, plot length was increased from 1 to $1.5 \mathrm{~m}$, which allowed only four plots per row. The number and variety of crops tested in the six replicated stars was reduced to corn or okra, canning tomato or eggplant, squash, and watermelon. Sweetpotato was evaluated in the outermost plots of the center star. The population of corn and okra was increased to 14 and

(continued on p. 763)

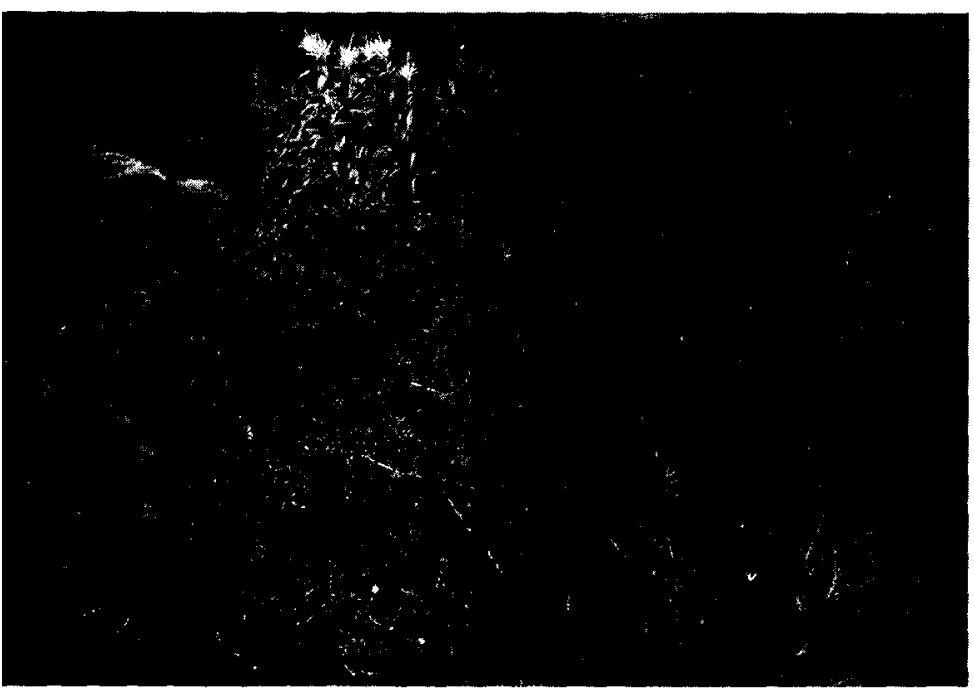

Fig. 1. A single "star" late in crop development showing the use of land area between rows by spreading and trailing crops. (Photograph by Ted Smith) 
26 plants per plot, respectively, to use the greater row length other crops were grown at the same number of plants per plot as in 1991.

Averaged across cultivars and years, yields (in kilograms per plot) of the most promising crops for each plot location in this test have been: corn, 2.8; canning tomato, 19.8; squash, 17.7; and watermelon, 29.0. Since watermelon does not contribute substantially to dietary quality, and much of its harvested weight is not edible, sweetpotato ( $13.3 \mathrm{~kg} / \mathrm{plot}$ ) maybe abetter alternative for production in the outermost plots.

The greatest constraint to productivity in the ASTER design appears to be overcrowding by some crops, especially in 1991 when there were six crop plots per $6 \mathrm{~m}$. Production of corn, okra, and sunflower was surprisingly low in this test, probably as a result of shading and overcrowding. Although these crops did not contribute substantially to food production, few other crops would likely perform well in the high-density planting of the innermost plots. Bean and pea productivity was unsatisfactory in 1991. It seems reasonable that climbing beans could be grown in conjunction with the tall crops to enhance the productivity of both crops in the innermost plots. Although pepper and eggplant were not productive, both fresh-market and taming tomato cultivars performed well; 'Roma' averaged $23.1 \mathrm{~kg} /$ plot over the two years of this test. Both winter and summer squash cultivars produced well over long periods in this test. Summer types averaged $22.9 \mathrm{~kg} / \mathrm{plot}$ over the two years, but winter types offer the added advantage of storage ease, which can be important in improving the diet of people in developing nations. The same advantage may be important in selecting sweetpotato for production in this scheme. Thus, it is apparent that a single 6-m row can reasonably produce $>50$ $\mathrm{kg}$ of vegetables. Hence, $300 \mathrm{~kg}$ can be produced from a six-row star consisting of $18 \mathrm{~m}^{2}$ of irrigated row space, or $\approx 100 \mathrm{~m}^{2}$ total area. Where vegetable production and consumption are limited by the cost of irrigated land and the labor of irrigating by hand, the efficiencies intended in the ASTER design should prove beneficial.

\section{Variations on the design}

The ASTER design can be the basis for myriad adaptations according to local needs

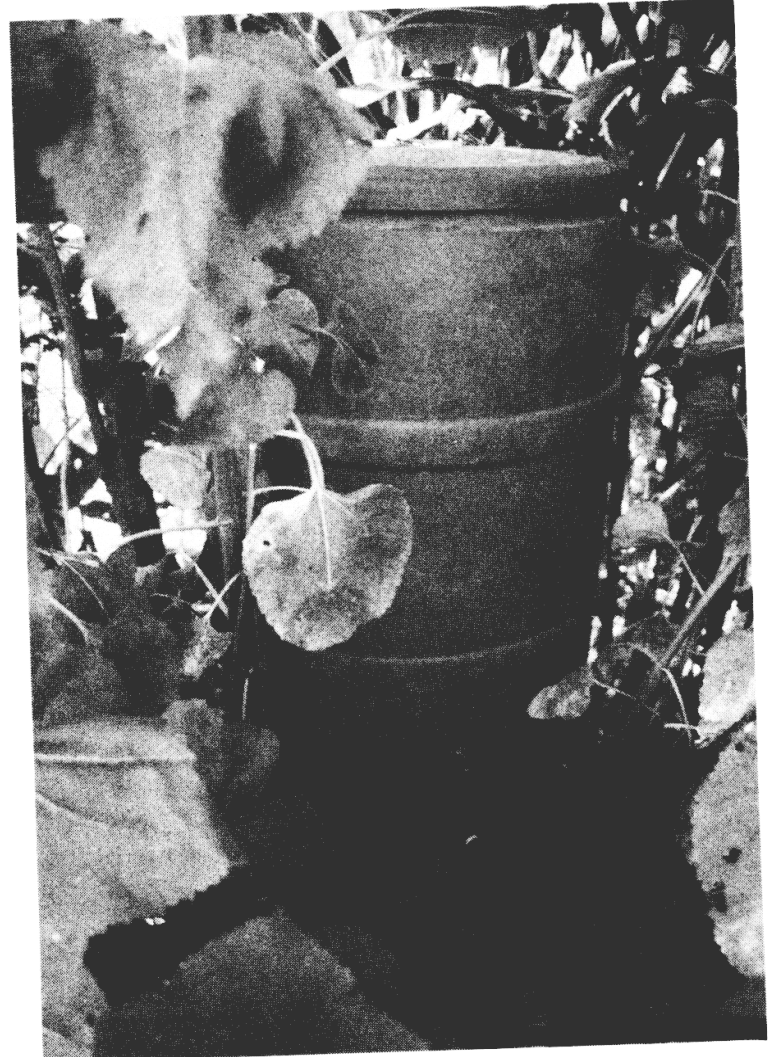

Fig. 2. The ASTER garden design allows the use of simple drip irrigation technology. To irrigate the center star, six drip irrigation tubes distribute water by gravity flow from this 200-liter barrel. (Photograph by Ruth Jarret)

and conditions. Several stars can be developed in a repeating pattern to provide more production area. Animal pens or compost piles can be located in the uncropped areas between divergent rows to use plant residue and provide compost or manure for planted rows. In addition, tree crops can be planted at the ends of irrigated rows, allowing the conversion from garden to orchard production overtime, when new garden areas can be developed.

This design requires irrigating only the narrow strip of row where plants are located, but assures-nearly complete ground cover and light interception within the garden area. The design also requires producing a variety of crops, thus enhancing dietary and economic diversification. It appears to be appropriate for international development applications and may also be used as a novel garden arrangement in developed countries.

\section{Literature Cited}

Beverly, R.B., S. George, and G.O. Gaye. 1991 Market gardening research and development in The Gambia. HortScience 26:724. (Abstr.)

Bittenbender, H.C. 1985. Home gardens in less developed countries. HortScience 20:645-449.

Jack, I. and J.S. Caldwell. 1988. Horticulture in The Gambia. HortScience 23:2.

Midmore, D.J., V. Ninez, and R. Venkataraman. 1991. Household gardening projects in Asia Past experience and future directions. Asian Vegetable Research and Development Center. Tech. Brd. 19.

Venkatamaran, R. 1992. Household gardening in Asia: A review. Asian Vegetable Research and Development Center. Working Paper 3.

Reuben B. Beverly

Dept. of Horticulture Georgia Experiment Station Griffii，GA 30223-1797 